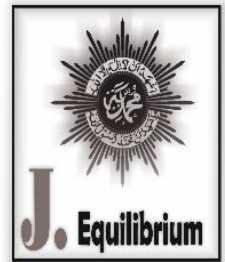

\title{
Strategi Pemberdayaan Ekonomi Komunitas Berkebutuhan Khusus Melalui Industri Kreatif di Sidosermo Indah, Surabaya
}

\author{
Anif Muchlashin \\ Departemen Pembangunan Sosial dan Kesejahteraan, FISIPOL, Universitas Gadjah Mada, Yogyakarta \\ Email : anif.m@mail.ugm.ac.id
}

\begin{abstract}
This study aims to see how the strategies used by Tiara Handicraft in empowering the economy of communities with special needs. This research uses a qualitative approach. The results obtained by the community with special needs can work with sufficient supporting facilities, a family attitude that is always put forward. They feel happy even though they are treated like normal humans in general. Ibu Titik Winarti as the founder has also received various awards at local, regional, national and international levels.
\end{abstract}

Keywords : Economic Empowerment, Special Needs Community, Creative Industry.

\begin{abstract}
Abstrak. Penelitian ini bertujuan untuk melihat bagaimana strategi yang digunakan oleh Tiara Handicraft dalam melakukan pemberdayaan ekonomi komunitas berkebutuhan khusus. Penelitian ini menggunakan pendekatan kualitatif. Hasil yang didapatkan para komunitas berkebutuhan khusus dapat bekerja dengan penunjang fasilitas yang cukup, sikap kekeluargaan yang sealu dikedepankan. Mereka merasa bahagia meskipun dengan perlakuan seperti manusia normal pada umumnya. Ibu Titik Winarti selaku pendiri juga telah mendapatkan berbagai penghargaan baik tingkat lokal, regional, nasional hingga internasional.
\end{abstract}

Kata Kunci : Pemberdayaan Ekonomi, Komunitas Berkebutuhan Khusus, Industri Kreatif.

Pendahuluan

Pada dasarnya manusia diciptakan oleh Allah SWT dengan bentuk yang paling baik dan sempurna, telah jelas diterangkan dalam nash Al Qur'an pada surat At Tiin ayat 4. Bukti kesempurnaannya Alloh menciptakan bentuk manusia adalah dengan bentuk dan rupa yang berbeda satu dengan yang lain, baik dilihat dari fisik seperti raut muka, bentuk rambut, warna kulit serta banyak hal lainnya yang berbeda, begitu juga berbedanya antara kaum normal dengan kaum cacat atau yang dikenal di Indonesia adalah kaum difabel, yang juga merupakan makhluk sempurna tetapi dengan bentuk kesempurnaan yang berbeda.

Makna difabel menurut kamus ilmiah adalah ketidakmampuan, cacat, ketidakcakapan sedangkan arti difabel menurut istilah adalah (differently able) atau kelompok manusia yang memiliki kemampuan yang berbeda, yakni sebuah istilah untuk menggantikan istilah disable atau penyandang cacat karena didalam maknanya mengandung stereotype negative dan bermakna disempowering. Sehingga disini kaum difabel dikatakan sebagai seorang yang tidak berguna dan tidak berdaya, sejalan dengan teori normalisme. Menurut teori norminalisme yang dikemukakan oleh Colin (1997) mengatakan bahwa kaum difabel adalah titisan setan, sedangkan pendapat lain yang dikemukakan oleh Foucault (1998) menilai bahwa difabel adalah sebagian dari penyakit dan patologi sosial, sehingga mereka pantas untuk di rehabilitas.

Bertolak dari paparan mengenai pengertian dan teori tersebut, sejarah membuktikan bahwa kaum difabel tidak hanya menjadi sebuah sampah yang tidak berguna dimasyarakat, seperti Apolinario Mabini seorang tokoh revolusioner kemerdekaan di negara Filiphina, berjuang sekuat tenaga untuk bebas dari jajahan Amerika Serikat. Dia menuliskan gambaran atau ide revolusi yang cemerlang, Apolinario juga ikut berperang langsung melawan penjajah sampai diasingkan ke Guam, 
dan membuat setiap orang kagum karena kakinya disfungsional sehingga ketika berjalan harus dibantu dengan alat tandu, sejarah ini membuktikan bahwa seorang penyandang difabel bukan hanya menjadi penyebab masalah dalam struktur masyarakat tapi juga dapat membuat prestasi yang besar.

Begitu juga di Indonesia, ada seorang perempuan bernama Ibu Titik Winarti, yang mendirikan sebuah indutri kreatif untuk peningkatan ekonomi komunitas khusus terutama kaum difabel, industri yang beralamat di Sidosermo II/5, Surabaya, dengan perusahaannya bernama tiara handycraft bergerak pada bidang seni kreatif, seperti pembuatan tas, baju dan perlengkapan sholat seperti sajadah, rukuh serta kerajinan lainnya, sampai saat ini Bu Titik Winarti mempunyai karyawan sebanyak 42 orang yang semuanya memiliki cacat fisik atau difabel, meskipun dibuat oleh orang difabel namun tidak berpengaruh pada kualitas terhadap hasilnya, barang tetap laku dipasaran dengan laba yang dihasilkan mencapai 60 Juta perbulan. Berdasarkan latar belakang yang diuraikan diatas, maka peneliti tertarik untuk melakukan penelitian ini.

\section{METODE PENELITIAN}

Dalam penyusunan penelitian ini, peneliti menggunakan metode kualitatif, yang disajikan dengan dengan cara deskriptif. Penelitian ini dilakukan dengan cara mencari data yang dikumpulkan berupa kata-kata bukan berdasarkan angka-angka. Proses analisisnya dengan intreprestasi, bukan menggunakan statistik atau cara kuantitatif maka jenis penelitian yang mampu menjawab alasan tersebut adalah metode kualitatif bukan kuantitatif.

Menurut Keirl dan Miller dalam Moleong yang dimaksud dengan penelitian kualitatif adalah "tradisi tertentu dalam ilmu pengetahuan sosial yang secara fundamental bergantung pada pengamatan pada manusia pada kawasannya sendiri, dan berhubungan dengan orang-orang tersebut dalam bahasanya dan peristilahannya" Adapun landasan teori yang digunakan dalam penelitian ini adalah fenomenologi, yaitu mencocokkan dan juga memahami peristiwa dan kaitankitannya terhadap orang-orang yang berada dalam situasi situasi tertentu. Sehingga apa yang ada di lapangan nantinya akan dicocokan dan dipahami dengan peristiwa-peristiwa yang berkaitan. Penekanannya pada penelitian ini adalah pada perilaku orang. Oleh karena itu penelitaian ini nantinya akan lebih ditekankan pada perilaku orang yang terkait dengan strategi pemberdayaan komunitas berkebutuhan khusus di Sidosermo Indah, Surabaya.

\section{HASIL PENELITIAN DAN PEMBAHASAN}

\section{A. Keadaan Orang Difabel}

Tiara Handycraft saat ini memiliki karyawan sebanyak 38 orang yang statusnya semua adalah penyandang cacat baik cacat fisik maupun mental, cacat fisik itu seperti tangan yang tidak normal, ada yang buntung, ada yang tangannya mengecil (polio), kaki buntung satu, kaki buntung dua, dan ada kecacatan fisik lain seperti mata tidak bisa melihat satu, dan yang satu rabun, dan ada yang tuna wicara maupun tuna rungu, tetapi semua yang mempunyai cacat fisik masih Allah berikan mental yang bagus, di Tiara Handycraft ini juga menaungi cacat mental yang sekarang ini ada satu yang cacat mental, tetapi masih bisa terkontrol, dan dari 38 orang itu 24 berjenis kelamin laki-laki dan yang 14 adalah perempuan..

Mayoritas para difabel ini berasal dari luar kota Surabaya, seperti Malang, Magelang, Jogjakarta, Blitar, Magetan, Jember, Madiun, Madura, dan Solo serta ada satu yang terjauh yakni dari Lombok, pada mulanya sebelum mereka di Tiara handicraft ini kebanyakan dari mereka sempat untuk mengikuti kursus di PSBD Tuna Daksa yang ada di Bangil dan ERCE yang ada di Solo, dengan berbagai bidang yang mereka bebas memilih sesuai bakat, minat dan kemauan, dengan rentan waktu selama satu tahun, mereka disana diajarkan berbagai keahlian dengan cara diberi sebuah pelatihan, seperti las, elektro, mesin jahit, kelistrikan, dan otomotive. Setelah satu setengah tahun diberikan pelatihan di Solo dan Bangil mereka dibebaskan untuk memilih untuk berwirausaha sendiri 
dengan dibekali peralatan yang lengkap atau disalurkan ke beberapa daerah salah satunya di Tiara Handycraft ini, memang PSBD Tuna Daksa di Bangil dan ERCE di Solo ini adalah semacam badan swasta LSM yang khusus menangani orang difabel di Indonesia. Secara lengkap akan dijelaskan melalui tabel nama orang difabel yang sekarang ini ada di Tiara handicraft berikut ini :

\begin{tabular}{|c|c|c|c|}
\hline No & Nama & Jenis Kelamin & Asal \\
\hline 1 & Siti & $\mathbf{P}$ & Surabaya \\
\hline 2 & Laely & $\mathbf{P}$ & Probolinggo \\
\hline 3 & Parijem & $\mathbf{P}$ & Madiun \\
\hline 4 & Purwanti & $\mathbf{P}$ & Mojokerto \\
\hline 5 & Anti & $\mathbf{P}$ & Lombok \\
\hline 6 & Ulya & $\mathbf{P}$ & Nganjuk \\
\hline 7 & Sri & $\mathbf{P}$ & Solo \\
\hline 8 & Leny & $\mathbf{P}$ & Malang \\
\hline 9 & Nining & $\mathbf{P}$ & Yogyakarta \\
\hline 10 & Istiana & $\mathbf{P}$ & Bangil \\
\hline 11 & Ria & $\mathbf{P}$ & Madura \\
\hline 12 & Supiah & $\mathbf{P}$ & Blitar \\
\hline 13 & Ayun & $\mathbf{P}$ & Blitar \\
\hline 14 & Cipluk & $\mathbf{P}$ & Ngawi \\
\hline 15 & Suroso Anata & $\mathbf{L}$ & Wonogiri \\
\hline 16 & Surogiri & $\mathbf{L}$ & Trenggalek \\
\hline 17 & Amin & $\mathbf{L}$ & Trenggalek \\
\hline 18 & Uklik & $\mathbf{L}$ & Malang \\
\hline 19 & Abdul Latip & $\mathbf{L}$ & Madiun \\
\hline 20 & Basori & $\mathbf{L}$ & Madura \\
\hline 21 & Robi & $\mathbf{L}$ & Ngawi \\
\hline 22 & Rohadi & $\mathbf{L}$ & Blitar \\
\hline 23 & Solikhin & $\mathbf{L}$ & Madiun \\
\hline 24 & Mohammad Nawawi & $\mathbf{L}$ & Magelang \\
\hline 25 & Wawan & $\mathbf{L}$ & Magetan \\
\hline 26 & Ahmadi & $\mathbf{L}$ & Jember \\
\hline 27 & Karim & $\mathbf{L}$ & Ngawi \\
\hline 28 & Suwardi & $\mathbf{L}$ & Blilar \\
\hline 29 & Shobirin & $\mathbf{L}$ & Blitar \\
\hline 20 & Guntur & $\mathbf{L}$ & Magetan \\
\hline 31 & Andun & $\mathbf{L}$ & Solo \\
\hline 32 & Sholeh & $\mathbf{L}$ & Nganjuk \\
\hline 33 & Yusuf & $\mathbf{L}$ & Nganjuk \\
\hline 34 & Untung & $\mathbf{L}$ & Blitar \\
\hline 35 & Harits & $\mathbf{L}$ & Malang \\
\hline 36 & Indra & $\mathbf{L}$ & Madiun \\
\hline 37 & Ilham & $\mathbf{L}$ & Banyuwangi \\
\hline 38 & Purnomo & $\mathbf{L}$ & Jember \\
\hline
\end{tabular}

\section{B. Prestasi Tiara Handicraft}

Berbagai penghargaan dari tahun ke tahun Tiara Handicraft telah didapatkan, dari tingkat lokal, regional, nasional dan internasional, dan berbagai sertifikat-sertifikat baik yang diberikan atas nama lembaga Tiara Handicraft maupun Ibu Tititk Winarti yang bersumber dari bidang goverment 
organisation atau non goverment organisation, untuk lebih lengkapnya sedikit peneliti catat dari berbagai prestasi yang terpampang pada setiap tembok dinding tempat tamu dan disitu juga tempat hasil dari karya difabel berada, beserta tahun dan pemberi insitusi yang akan digambarkan melalui tabel dibawah ini :

\begin{tabular}{|c|l|l|l|}
\hline No & \multicolumn{2}{c}{ Nama Prestasi } & PBB \\
\hline 1 & Micro Credit Award & Lembaga Sosial Asia & 2005 \\
\hline 2 & Pembicara Asian Forum & Presiden RI & 2006 \\
\hline 3 & Satya Lencana & $\begin{array}{l}\text { Walikota Surabaya } \\
\text { Perempuan }\end{array}$ & 2008 \\
\hline 5 & $\begin{array}{l}\text { Penghargaan Pemberdayaan } \\
\text { Difabel }\end{array}$ & KEMENSOS RI & 2009 \\
\hline 6 & $\begin{array}{l}\text { International Industry Creative } \\
\text { Difabel }\end{array}$ & Lemsos Internasional & 2009 \\
\hline 7 & Kecamatan Award & Camat Sidosermo & 2010 \\
\hline
\end{tabular}

\section{Manusia Difabel di Tengah-Tengah Pengucilan Masyarakat dan Keluarganya}

Kenyataan dilapangan telah sesuai dengan teori yang telah dipaparkan di pembahasan kedua, yakni adanya patologi sosial atau pengucilan di lingkungan asal orang difabel, sesuai dengan pengertian dasar difabel sendiri diartikan sebagai penyandang cacat yang terkadang para masyarakat disekitarnya lebih mengartikan dan memandang sebagai manusia yang tidak berguna atau disfungsional baik dalam kehidupannya pribadinya, keluarganya maupun dalam lingkungan sistem sosialnya.

Pengalaman dari beberapa orang difabel di Tiara Handicraft menceritakan sendiri bahwa posisi mereka dihadapan para masyarakatnya dipandang sebagai mahluk yang lebih baik tidak untuk dilahirkan, bukan hanya dilingkungan masyarakatnya tetapi yang lebih ekstrem lagi adalah dalam lingkup intern keluarganya-pun juga dimikian, beberapa hal kejadian yang mereka alami serupa, yakni ketika ada tamu datang kerumahnya manusia difabel ini disuruh masuk kekamarnya dan tidak boleh dipersilahkan keluar sebelum tamu itu keluar dari rumahnya, atas dasar malu ketika orang lain melihat salah satu anggotanya ada yang tidak normal, dan memiliki kekurangan dalam hal fisik, tapi tidak hanya itu orang-orang yang difabel juga dipersulit untuk meneruskan keturunannya dalam artian lain bahwa orang difabel dilarang menikah, karena ketakutan mereka akan berimbas nantinya pada anak yang akan dilahirkan nanti mengikuti garis keturunan difabel, begitu juga didukung oleh faktor lain, selayaknya orang normal jarang bahkan tidak ada yang mau untuk dijodohkan ataupun mencari jodoh pasangan baik suami atau istri yang mempunyai kecacatan fisik.

Berbagai masalah mereka temui baik dari keluarga sendiri ataupun dalam masyarakatnya, dari konteks masyarakatnya juga mereka menemui berbagai macam masalah, salah satu contohnya yakni ketika mereka keluar dari rumahnya dan dilihat oleh orang lain, terutama orang yang sedang hamil ia selalu mengalihakan pandangannya dengan alasan agar anaknya yang akan terlahir tidak mengikuti seperti apa yang dialami oleh manusia difabel ini, bukan hanya sekedar itu dari pengalaman yang ada mereka juga pernah diusir supaya mereka menghilang atau minimal tidak terlihat dari pandangannya, sehingga akses interaksi mereka dalam konteks keluarga dan sistem sosialnya terbatas, sesuai dengan pendapat Gillin dan Gillin yang mengatakan bahwa patologi sosial akan 
memunculkan adanya ketidakserasian atau pengucilan individu didalam sebuah komunitas atau masyarakat yang mengakibatkan hancurnya ikatan sosial mereka, serta hubungan yang tidak harmonis bahwan terkadang memunculkan konflik.

Lanjut dari teori Gilin dan Gilin menyatakan bahwa penyebab hal ini dikarenakan adanya pengaruh dari beberapa faktor diantaranya karena kemiskinan, pengangguran, masalah-masalah orang yang telah lanjut usianya, insaty, kejahatan, perceraian, pelacuran, dan penyandang cacat, yang dalam hal ini merangkap antara penyandang cacat dengan kemiskinan yang kebanyakan melekat pada mereka, dari sini sangatlah disayangkan hanya karena cacat fisik mereka mendapat beban mental yang berat, terkadang mereka juga bingung untuk lari kemana, bergabung dengan siapa yang sekiranya dapat meredakan pengucilan-pengucilan yang banyak mereka dapatkan.

\section{Pemberdayaan oleh Tiara Handicraft}

Telah jelas dipaparkan adanya faktor-faktor yang dipaparkan diatas, yang kemudian akan memunculkannya sebuah pemikiran lain, yang dari sini peneliti katakan adanya faktor desakan dan dorongan, dari sisi faktor desakan mereka menemui adanya berbagai masalah seperti munculnya berbagai pengucilan baik dari pihak keluarga sendiri maupun dari masyarakat pada umumnya yang kemudian dapat memunculkan pemikiran yang kemungkinan mengarah kepada pola pikir beralih dan bergabung ke panti rehabilitasi sosial, tetapi dari lain sisi adanya faktor pendorong yakni dari belenggu sisitem ekonomi kemiskinan yang membalut mereka para kaum difabel tidak bisa keluar begitu saja melainkan mereka masih memiliki atau ada tanggungan untuk menafkahi keluarga yang tidak jarang diantara mereka sebagai tulang punggung keluarga, serta keadaan dari mereka keluarganya berada pada keadaan menengah kebawah.

Dari sinilah Tiara Handicraft sebagai jalan keluar yang tepat untuk mengatasi masalah-masalah orang difabel, yang peneliti kelompokan menjadi 3 fungsi pokok, yakni untuk keluar dari sistem sosianya, menolak panti rehabilitasi dan sekaligus membantu ekonomi keluarganya, di Tiara Handicraft ini mereka ingin membuktikan bahwa mereka dapat mandiri bahkan dapat membuat manfaat pada keluarganya, atasa dasar inilah sampai saat ini Tiara Handicraft sudah menaungi orang-orang difabel dengan masalah yang tidak jauh berbeda yang dapat ditotal dari tahun awal mula berdiri yakni tepatnya tahun 1999 sampai tahun 2014 Tiara Handicraft mengayomi 500 lebih orang difabel.

\section{E. Strategi Pemberdayaan Tiara Handycraft}

Strategi yang dibangun di Tiara Handicraft ini berbeda dengan industri lainnya, secara rinci strategi yang pertama ia lakukan ketika orang difabel datang ke Tiara Handicraft adalah mereka dibiarkan selama satu minggu untuk melakukan proses adaptasi sembari melihat-lihat proses yang berjalan yang dilakukakan oleh para senior, pada minggu berikutnya mereka para kaum difabel dipersilahkan untuk memilih dan mencoba satu bidang devisi dari empat devisi yang tersedia yakni, ada potong, jahit, sablon, dan finishing, mereka mencoba satu persatu, dan pada akhirnya nanti ia dapat memilih salah satu bidang yang akan ia tekuni.

Dari empat devisi yang ada didalamnya ada sub bagian pekerjaanya, yang pertama adalah devisi potong didalamnya ada bagian untuk menyetok persediaan barang, dan urusan gudang, devisi yang kedua yakni devisi jahit mereka khusus untuk produksi kegiatan sulam dan bordir, yang ketiga adalah devisi sablon yang mereka khusus bergerak untuk menangani penyablonan, dan yang terakhir adalah finishing termasuk didalamnya ada setrika, quality control, dan packing, setelah memilih dan mencoba mereka tetap terus dibimbing pelan-pelan oleh senior yang sudah lama menekuni devisi yang ada, sampai tujuan akhirnya adalah mereka dapat mengelola mesin dan melakukannya tugasnya secara lancar, handal dan profesional.

Hal diatas adalah strategi yang pertama diterapkan pada orang difabel yang belum mahir, sedangkan bagi mereka yang sebelumnya sudah pernah mengikuti training selama satu tahun dengan bidang yang sama baik di PSBD Tuna Daksa Bangil ataupun ERCE yang berada di Solo, mereka 
langsung memelih bidangnya tanpa melalui adaptasi, tetapi pada orang difabel yang ikut pelatihan tetapi bukan dalam bidang yang sama, seperti otomotive, las, listrik, dan lain sebagainya ataupun juga tetap ia akan dilatih sedetail dan sesabar mungkin oleh senior yang sudah mahir, dan mereka juga dibebaskan pindah ke devisi lain jikalau di devisi yang sedang dilakoninya tidak sesuai dengan kemampuannya, tidak ada jangka batas waktu pelatihan tertentu, melainkan mereka dilatih sampai bisa.

Dari strategi yang diterapkan telah jelas bahwa teori yang digunakan adalah technocratic. Pendekatan technocratic menurut pendapat Combs dan Ahmed (1980) menyatakan bahwa memungkinkan melaksanakan perubahan dan pembaharuan yang dimulai dari suatu tindakan dari luar berupa suatu tindakan memperkenalkan dan memaksakan program secara sepihak, dari indikator yang ada bahwa Tiara Handicraft ini lebih bersifat pemaksaan keahlian tidak menghendaki bakat potensi apa yang mereka punya, pilihannya sempit tidak meluas, tidak ada indikator memberikan kuasa baik 'kekuasaan didalam' (power within), 'kekuasaan untuk' (power to), 'kekuasaan atas' (power over) dan 'kekuasaan dengan' (power with).

Tidak seperti pendekatan lawannya yakni pendekatan selfhelp yang dalam memberdayakan masyarakat atau komunitas mengutamakan sumber, potensi dan kekuatan dari dalam, sedangkan prinsip pendekatan yang digunakan adalah prinsip demokrasi serta prinsip menentukan nasibnya sendiri, penempatan prinsip ini didasarkan pada prinsip penempatan pemberdayaan yang bersifat humanis yang mengakui keberdaan manusia sebagai makhluk aktif dan kreatif, asumsi yang mendasarinya adalah bahwa masyarakat sendiri dapat menjadi pelaku yang sangat berarti sekaligus menjadi pengendali proses pemberdayaan, hal ini disebabkan karena pada dasarnya setiap masyarakat mempunyai kemampuan dan potensi untuk berkembang atas kekuatan sendiri.

Dari pendekatan ini menurut teori Soetomo (2008) yang menyatakan bahwa pendekatan selfhelp yang dibangun secara mandiri dan bersifat partisipatif ini akan berdampak pada pelaksanaan pemberdayaan yang berkelanjutan atau suistanable develpment lebih bersifat mendidik masyarakat atau komunitas agar untuk tidak tergantung dari luar serta memuun percaya diri, sehingga pelaksanaannya berkesinambungan. Dalam hal ini petugas lapangan disini ditempatkan sebagai fasilitator atau edukator, berbanding terbalik dengan pendekatan technocratic yang mana ia lebih mementingkan keberhasilan program dan hasil material, moderat dalam kecepatan menumbuhkan perubahan, serta potensi untuk menumbuhkan pemberdayaan secara berkelanjutan semakin lebih rendah.

Disamping itu menurut analisis peneliti bahwa Tiara Handicraft ini bukan sebagai suatu wirausaha yang bergerak dalam kegiatan pemberdayaan secara totalitas dan bukan menempatkan orang difabel sebagai obyek pemberdayaan melainkan orang difabel sebagai subjek bahkan menempatkan mereka (para kaum difabel) sebagai karyawan biasa untuk menarik para palanggan agar memiliki nilai jual pemasaran yang lebih tinggi sesuai dengan konsep entrepeneur yang dinyatakan Joseph Schumpeter Ekonom alsi Austrian yang dalam teorinya ia menekankan pada inovasi, seperti, produk baru, metode produksi baru, pasar baru, dan bentuk baru dari organisasi. Kemakmuran tercipta ketika inovasi-inovasi tersebut menghasilkan permintaan baru, yang disini orang difabel sebagai media untuk memberikan niali jual tinggi dalam konsep kewirausahaan.

Dari pernyataan yang disampaikan operatioal manager bahwa orang normal dengan orang cacat adalah jikalau orang normal dapat membuat kerajinan tangan sehari 1-3 buah tetapi para difable ini membuat 1 kerajinan yang dikerjakan oleh 3 orang, tetapi yang ditekankan disini adalah bukan kuantitatif atau jumlahnya namun dilihat dari prosesnya, ke-detailannya dan segi kualitasnya, sehingga barang hasil kerajinannya cenderung mempunyai daya jual yang tinggi, membeli suatu barang dengan disertai dengan belas kasihan dan sebagai infaq sosial, sehingga kata Mas Ade walaupun dikerjakan oleh orang difabel beliau mengaku bahwa penghasilan yang didapatkan mencapai 60 Juta perbulannya, telah jelaslah orientasi yang mereka katakan sebagai pemberdayaan tetapi mereka lebih mengutamakan omset sebagaimana industri-industri lainnya yang berada di luar.Bukan hanya itu mereka para kaum difabel mempunyai tanggungan jam kerja, jam kerja mereka adalah dari jam 07.30 sampai jam 16.00, dengan waktu istirahat satu setengah jam yakni jam 12.00 
sampai jam 01.30, dan apabila mereka merasa kurang dapat menambah jam kerja tambahan atau lembur dari setelah Isya 19.30-21.00, yang disini tidak ada tuntutan sama sekali dari pihak Tiara Handicraft, tetapi sistem yang ditanamkan disini adalah sistem upah, jadi semakin banyak hasil yang diperoleh maka semakin banyak pula upah yang akan didapatkan, ini merupakan sebuah pemaksaan secara halus yang diberikan oleh pihak Tiara handicraft, dilihat dari gajih kotor ketika mereka tidak ikut lebur hanya diberi gaji pokok 400 ribu, padahal secara tuntutan ekonomi mereka sangat memerlukan penghasilan ini untuk kehidupan orang tuanya, apalagi mereka yang menjadi tulang punggung keluarganya, ada pula beberapa orang yang sudah menikat dan mempunyai anak, tentu sistem lembur ini tetap dilakukan meskipun dengan keadaan fisik yang letih dan lesu, atas dasar penyamaan dengan orang normal maka Tiara Handicraft tidak segan-segan melakukan hal ini, mereka mencoba untuk menerapkan kedisiplinan selayaknya orang normal, karena memang sesuai dengan tujuan mendirikan lembaga Tiara Handiraft ini yang akan memberikan kesempatan kepada orang-orang difabel dengan tidak hanya memberikan belas kasihan semata, tetapi kenyataan dilapangan sebenarnya orang difabel merasa keberatan dan tidak kuat, walau bagaimana-pun mereka adalah orang difabel yang mempunyai kekurangan fisik, atas dasar alasan inilah beberapa orang dari mereka memilih untuk keluar.

\section{F. Sistem Keluargaan dan Anggapan Sebagai Orang Normal Menjadi Jargon}

Strategi yang lain yang Tiara Handicraft bangun disini ialah sistem kerja yang dibangun adalah atas sistem kekeluargaan, jadi satu sama lain disana saling bantu membantu, bukan hanya itu melainkan mereka juga saling curhat mengenai masalah pribadi ataupun tentang pekerjaannya, seperti selayaknya saudara kandung dan anggota keluarganya sendiri, sehingga mereka merasa nyaman dan tenang ditengah-tengah jauhnya keberadaan mereka dengan keluarga, sanak saudara, istri dan anak, Mas Ade menuturkan juga bahwa sistem kekeluargaan disini bukan antar orang difabel melainkan dengan Bapak Dermawan Yudha selaku pemilik Tiara Handicraft, Ibu Titik Winarti dan Mas Ade Rizal yang beliau sebutkan sebagai sistem satu kesatuan yang saling berintegrasi, ia membuat jargon ketika kita bersatu maka kita akan bisa melakukan apapun dan ketika kita bercerai maka kita tidak bisa melakukan sesuatu hal apapun seperti konsep manajemen organisasi. Disisi lain dari berbagai macam pengalaman orang difabel dapatkan dikampung halamanya yakni pengucilan sebagai orang cacat yang tidak berguna berbanding terbalik dengan sistem Tiara Handiraft yang dibuat, atas dasar itulah mereka (para pegawai Tiara Handicraft) membuat sebuah konsepan untuk mengembangkan dan menyikapi mereka para difabel sebagaimana orang normal, dari Tiara Handicraft sendiri tidak melihat dan mengatakan mereka dengan kecacatan dan mempunyai kekurangan, tetapi mereka dihadapkan seperti selayaknya orang normal serta sebagai sesama makhluk Tuhan yang mempunyai kesempurnaan dengan aspek yang lain, terbukti dengan kejadian realistis yang terjadi dilapangan mereka tidak diperlakukan secara khusus baik dari segi fasilitas ataupun dari perlakuan sikapnya, mereka dipandang dan diperlakukan secara sama selayaknya orang normal biasa.

\section{KESIMPULAN}

Berdasarkan pembahasan hasil penelitian di atas, diperoleh kesimpulan yang berkenaan dengan Kasus Strategi Pemberdayaan Ekonomi Komunitas Berkebutuhan Khusus Melalui Industri Kreatif di Sidosermo Indah, Surabaya, sebagai berikut:

1. Tiara Handicraft ini merupakan sebuah lembaga resmi swasta yang mempunyai izin resmi dari pemerintah yang bergerak pada bidang usaha yang dikerjakan oleh orang difabel, yang dibelakangnya dibantu oleh sebuah Yayayasan swasta bernama Yayasan Bina Karya Cipta Tiara yang juga turut berkontribusi dalam bantuan lembaga hukum dan ikut memberikan berbagai macam pemenuhan kelayakan hidup seperti melalui pelatihan-pelatihan, pendidikan, penjaminan kesehatan dan lain sebagainya. 
2. Usaha pemeberdayaan ini tidak sengaja, karena pada awal mulanya Tiara Handicraft ini sebuah usaha yang seperti selayaknya yang lain melayani dan mengayomi orang normal, tetapi melihat semangat dan antusiasme orang difabel ketika diberi kesempatan kerja maka Tiara Handicraft berinisiatif menjadikan sebuah usaha untuk menaungi kaum difabel yang pada dasarnya bukan untuk kepentingan materi tetapi juga sebagai bentuk fungsi sosial membantu sesama.

3. Perkembangan dari tahun ketahun sangat pesat dimulai dari tahun 1999 yang memberdayakan 2 orang sampai pada puncaknya tahun 2006 Tiara Handicraft menaungi 67 orang difabel, dan sampai sekarang ini adalah 38 yang keadaanya berbagai keadaan cacat fisik dan mental, juga keberagaman terjadi pada keadaan para kaum difabel yang berasal dari berbagai asal di penjuru Indonesia, seperti Surabaya sendiri, Nganjuk, Ngawi, Madiun, Blitar, Malang, Jogjakarta, Solo, Madura bahkan Lombok. Sarana prasarana di Tiara Handicraft ini dicukupi dengan baik demi untuk kenyamanan dalam melakukan upaya menyelesaikan berbagai macam pekerjaan yang harus digarapnya, dimulai dari tempat kerja yang nyaman, adanya AC, alat bantu yang super canggih dan modern, asrama yang tersedia, tiga wc, dan musholla juga disediakan.

4. Orang difabel ini tertarik untuk bergabung dengan Tiara Handicraft ini karena beberapa faktor, faktor ini muncul dari dalam dan luar. Dari dalam misalnya adanya patologi sosial dari lingkungan tempat tinggalnya, adanya keengganan untuk bergabung dengan rehabilitasi sosial atau PAC (pendidikan orang cacat) yang selalu dibedakan, dan adanya faktor dari luar adanya kemiskinan yang sering sekali kesempatan ini tidak banyak dijumpai di Indonesia, makanya bergabung dengan Tiara Handicraft ini sebagai "pelarian" atau secara halusnya sebagai opsi terakhir sebagai jalan keluar atau solusi terbaik.

5. Strategi yang Tiara Handicraft ini berbeda dengan lembaga lain karena obyeknya juga berbeda, yakni dengan penuh kesabaran dan membutuhkan waktu yang lama untuk menjadikan mereka menjadi profesional, bukan hanya itu tetapi Tiara Hndicraft juga mengedepankan sistem kekeluargaan dan penyerataan orang normal yang mereka tidak bisa didapatkan di tempat lain.

6. Secara umum para kaum difabel sebagai obyek pemberdayaan merasakan senang dalam ucapannya karena apa dari sarana dan prasarana dimudahkan, sistem kekeluargaan, meskipun mereka kadang terlalu lelah karena jam kerja yang tidak sesuai dengan keinginan orang difabel, begitu juga keterkaitan dengan sistem gaji yang tidak bisa ditolak sistemnya yang biasa diartikan sebagai keterikatan.

\section{DAFTAR PUSTAKA}

A Partanto, Pius dan M. Dahlan Al Barry, 1994. Kamus Ilmiah Populer, Yogyakarta: Arkola. Arikunto, 2006. Prosedur Penelitian Suatu Pendekatan Praktik, Jakarta: PT Rineka Cipta.

Biro Hukum Departemen Sosial RI. Peraturan Pemerintah No. Tahun Tentang Upaya Peningkatan Kesejahteraan Sosial Penyandang Cacat, Jakarta: Depdiknas.

Coloridge, 1997. Pembebasan dan Pembangunan, Perjuangan Penyandang Cacat di Negara-Negara Berkembang, Yogyakarta: Pustaka Pelajar.

Departemen Agama RI, 2007. Al-Qur'an dan Terjemahannya, Bandung: Syaamil Qur'an.

Effendi, Muhammad . 2006. Pengantar Psikopedagogik Anak Berkelainan, Jakarta: Bumi Aksara.

W. J. S. Poerwodarminto, 1999. Kamus Besar Bahasa Indonesia, Jakarta: Balai Pustaka.

Gerungan, 2009. Psikologi Sosial, Bandung: PT Refika Aditama.

Husman dan Purnomo, 1996. Metodologi Penelitian Sosial, Jakarta: Bumi Aksara.

J. Moleong, Lexy. 2000 Metodologi Penelitian Kualitatif, Bandung: PT Rosydakarya. 2004. Metode Penelitian Kualitatif, Bandung: PT Remaja Rosdakarya.

Lock, Jessica. 2011 Pendapatan dan Perubahan Terhadap Difabel, Malang: UMM.

Moh. Ali Aziz, dkk. 2005. Dakwah Pemberdayaan Masyarakat: Paradigma Aksi Metodologi, Yogyakarta: Putaka Pesantren. 
Simandjutak, 1981. Beberapa Aspek Patologi Sosial, Bandung: Alumni. 1985. Patologi Sosial, Bandung: Tarito.

Soematri, T. Sutjihatini. 2006. Psikologi Anak Luar Biasa, Bandung: Refika Aditama.

Soetomo, 2008. Strategi-Strategi Pembangunan Masyaakat, Yogyakarta: Pustaka Pelajar.

Suharto, Edi, 2010 Membangun Masyarakat Memperdayakan Rakyat, (Kajian Strategis Pembangunan Kesejahteraan Sosial Dan Pekerjaan Sosial), Bandung: PT Refika Aditama.

Tim Penyusun Kamus Pembinaan Dan Pengembangan Bahasa, 2003. Kamus Besar Bahasa Indonesia Jakarta: Balai Pustaka.

Vembrianto, 1984. Pathologi Sosial, Yogyakarta: Paramita.Yatmo Hutomo, Mardi. 1996. Pemberdayaan Dalam Bidang Ekonomi: Tinjauan Teoritik dan Implementasi, Jakarta: CSIS.

Peter Coleridge, Pembebasan dan Pembangunan, Hal. 86

Jurnal :

Rahbini, Pendidikan Inklusif, Sebuah Konstruksi Pendidikan Anti Diskriminasi Bagi Difabel, dalam Jurnal Kependidikan Islam, Vol. 2, No. 1, 2012.

Tarsidi, Didi. Mengatasi Masalah-Masalah Psikososial Akibat Ketunaetraan Pada Usia Dewasa, dalam Jurnal Pendidikan dan Kebudayaan Vol. 18,

Nomor 1, Januari 2012.

Tohari, Slamet. Kemerdekaan Dalam Kuasa Normalisme, dalam Jurnal Maarif Vol. 3, No. 3, Tahun 2008.

Makalah :

Parsudi Suparlan, 1983. Metode Pengamatan, (Makalah dalam seminar Penelitian dan Kebudayaan DEPDIKBUD.

\section{Skripsi:}

Ainul Mu'jibah, Pemberdayaan Difabel Melalui Program Pengembangan Karakter, dalam skripsi, FD IAIN Surabaya, 2008.

\section{Wawancara :}

Wawancara dengan Ibu Titik Winarti, (Owner Tiara Handycraft), 18 April 2019.

Wawancara dengan Mas Ade Rizal 21 Mei, 11 Juni 2019.

Wawancara dengan Mas Amin 02 Juni 2019.

Wawancara dengan Mas Uklik dkk 02 Juni 2019. 